\title{
INFESTASI CACING SALURAN PENCERNAAN PADA KAMBING KACANG PERANAKAN ETTAWA DI KELURAHAN AMBAN KECAMATAN MANOKWARI BARAT KABUPATEN MANOKWARI PROVINSI PAPUA BARAT
}

\author{
Gastrointestinal Helminth Infestation on Ettawa Crossbreed Goat in Amban Subdistrict Manokwari \\ Barat District Manokwari Regency West Papua Province
}

\author{
Purwaningsih, Noviyanti, Priyo Sambodo
}

Diploma Program of Animal Health, Animal Husbandry Faculty, Universitas Papua

J1. Gunung Salju, Amban, Post Code. 98314 Papua Barat

email : ningsihaji@gmail.com

\begin{abstract}
The study was done to determine a general health feature of goat reared on semi intensive system especially on gastrointestinal worms parasites infestation. Research location were chosen based on the higher population in one location home farmers. Thirtytwo goats was 4 weeks - 3 years old that reared in the stage shed model examined fecal sample for knowing prevalence of gastrointestinal worm. The examination method fecal sample used natif and sedimentation methods. Based on the results of investigation fecal sample shows that prevalence of gastrointestinal worm infestation on goat reared in the stage shed model was 100\%. The goats were infected with Strongyle sp, Strongyloides sp, Haemonchus spp, Bunostomum spp, Trichostrongilus spp, dan Cooperia spp.
\end{abstract}

Keywords : Infestation, Gastrointestinal Worm, Ettawa Crossbreed Goat, Stage Shed

\section{PENDAHULUAN}

Populasi ternak kambing pada tahun 2014 di Indonesia diperkirakan sekitar 17,90 juta ekor (Ditjenak, 2014). Pertumbuhan populasi kambing dari tahun 2012 ke 2013 sebesar 5,36\%. Kambing kacang merupakan kambing asli Indonesia, sedangkan kambing kacang yang dikawin-silangkan dengan Peranakan Ettawa (KPE) memiliki tubuh yang lebih besar dibandingkan kambing kacang. Keunggulan lain dari kambing ini adalah sangat cepat berkembang biak, pada umur 1518 bulan sudah bisa menghasilkan keturunan, cocok sebagai penghasil daging, bersifat prolifik dan tahan terhadap berbagai kondisi serta mampu beradaptasi dengan baik di berbagai lingkungan yang berbeda termasuk dalam kondisi pemeliharaan yang sangat sederhana (Pamungkas et al., 2009).

Kambing kacang mampu beradaptasi pada lingkungan yang berbeda dan sederhana, hal ini memberikan kemudahan kepada peternak untuk menentukan manajemen dan sistem pemeliharaan. Sistem pemeliharaan secara semi-intensif dinilai merupakan salah satu metode pemeliharaan yang dapat diterapkan pada kambing kacang (Suhardono et al., 2001). Keunggulan dari sistem pemeliharaan secara semi-intensif diantaranya biaya produksi rendah serta tenaga kerja yang dibutuhkan juga sedikit. Selain itu dengan sistem pemeliharaan ini ternak dapat mengekspresikan tingkah laku alaminya (Animut et al., 2005), namun dalam penerapan sistem pemeliharan ini, ternak sangat rentan terserang oleh pengakit parasitik.

Salah satu penyakit parasitik yang sering menjadi permasalahan pada ternak kambing namun sering diabaikan oleh peternak adalah penyakit cacingan yang disebabkan oleh cacing saluran pencernaan (gastrointestinal) (Hanafiah et al., 2002). Parasit cacing saluran pencernaan merupakan masalah utama yang menyebabkan gangguan kesehatan pada ternak khususnya ruminansia kecil. Kambing dan domba merupakan ternak yang mudah terinfestasi oleh parasit cacing saluran pencernaan baik secara klinis maupun subklinis di negara berkembang (Zeryehun, 2012) dibandingkan dengan ternak yang lain karena kebiasaannya merumput (Schoenian, 2003).

Kerugian yang ditimbulkan akibat infestasi cacing saluran pencernaan diantaranya adalah menurunkan performa produksi dan reproduksi (Ayaz et al., 2013) disamping juga menurunkan feed intake dan feed conversion efficiency (Kanyari et al., 2009), terutama pada kondisi penyerapan nutrien yang tidak baik akan menghambat pertumbuhan (Terefe et al., 
2012) akan memicu terjadinya anemia dan bahkan kematian pada infestasi parasit cacing yang berat (Hassan et al., 2011). Di samping itu, infestasi parasit cacing akan menimbulkan lemahnya kekebalan tubuh, sehingga ternak lebih rentan terhadap infeksi penyakit pathogen lain dan akhirnya akan menyebabkan kerugian ekonomi (Garedaghi et al., 2011).

Mengingat infestasi cacing saluran pencernaan merupakan masalah utama penyebab gangguan kesehatan pada kambing kacang peranakan ettawa yang dipelihara secara semi-intensif, dan besarnya kerugian ekonomi yang ditimbulkan, maka perlu kiranya dilakukan penelitian dengan tujuan untuk mengetahui tingkat infestasi dari cacing saluran pencernaan pada kambing kacang peranakan ettawa.

\section{MATERI DAN METODE}

Penelitian dilakukan pada pemeliharaan semi intensif milik warga kelurahan Amban Kecamatan Manokwari Barat Kabupaten Manokwari Provinsi Papua Barat. Lokasi pengambilan sampel ini dipilih secara purposive sampling karena mempunyai populasi kambing yang cukup banyak (Thrusfield, 2007). Kambing diumbar di pekarangan/kebun setiap hari selama pemeriharaan, kambing dikeluarkan dari kandang sekitar jam 10 pagi sampai jam 3 sore. Pada sore hari kambing dikandangkan kembali secara individu.

Alat yang digunakan antara lain botol plastik sampel, spidol, pengaduk, kertas tisu, beaker glass, saringan teh, tabung pemusing, sentrifugator, rak tabung reaksi, pipet pasture, mikroskop, object glass, dan cover glass. Bahan yang diperlukan untuk penelitian ini adalah feses kambing ( $\pm 10 \mathrm{~g}$ feses ) yang diambil per rektal, formalin $10 \%$ untuk mencegah menetasnya telur sekaligus untuk mengawetkannya, larutan $\mathrm{NaCl}$ jenuh dan air.

Metode pemeriksaan sampel feses menggunakan uji sedimentasi. Cara kerja metode ini adalah feses diambil $\pm 2-4$ gram dan dimasukkan ke dalam beaker glass, ditambahkan air dan diaduk hingga homogen kemudian disaring. Cairan yang lolos dituangkan ke dalam tabung sentrifuse sampai $3 / 4$ volume tabung kemundian disentrifuse dalam sentrifugator dengan kecepatan 1500 rpm selama 2-3 menit. Supernatannya dibuang, kemudian ditambahkan $\mathrm{NaCl}$ jenuh hingga volumenya mencapai $3 / 4$ volume tabung, dan diaduk hingga homogen. Lakukan sentrifuse kembali selama 2-3 menit dengan kecepatan
1500 rpm. Tabung dikeluarkan dan diletakkan tegak lurus pada rak tabung reaksi, ditambahkan $\mathrm{NaCl}$ jenuh dengan cara diteteskan menggunakan pipet pasture sampai permukaan cairan cembung dan didiamkan hingga 3 menit. Cover glass ditempelkan pada permukaan yang cembung secara perlahan, lalu ditempelkan pada object glass dan diperiksa dengan mikroskop dengan pembesaran obyektif 40x. Jenis telur cacing yang ditemukan diidentifikasi berdasarkan morfologinya dengan mengacu pada Thienpont et al. (1986). Apabila terdapat satu jenis telur cacing dalam pemeriksaan, maka dikategorikan terinfestasi cacing saluran pencernaan, yang dinyatakan dengan hasil positif dan negatif.

Data hasil penelitian diolah dengan statistik deskriptif melalui perhitungan persentase, dan rata-rata yang akan ditampilkan dalam bentuk tabel. Hasil analisis dibahas secara deskriptif sesuai dengan literatur yang terkait.

\section{HASIL DAN PEMBAHASAN}

Pada umumnya ternak kambing dipelihara dalam kandang panggung dengan lantai bercelah. Kondisi kambing kurang bagus, bulu sekitar pantat kotor, kurus dan banyak feses yang lembek berserakan di lantai kandang. Kelainan klinis yang dapat ditemukan antara lain mencret. Ternak biasanya hanya menunjukkan gejala subklinis yang tidak begitu diperhatikan oleh peternak, hal ini akan bertambah kronis seiring dengan kurangnya nutrien yang diberikan untuk ternak dan tingkat stres yang meningkat, akan membuat parasit berproliferasi dengan lebih baik sehingga siklus hidupnya dapat berlangsung (Mulatu et al., 2012).

Sejumlah 32 sampel feses kambing kacang peranakan ettawa telah diperiksa secara laboratorik untuk diamati tingkat infestasi cacing saluran pencernaan. Hasil pemeriksaan tersebut tersaji dalam Tabel 1.

Tingkat kejadian infestasi cacing saluran pencernaan pada kambing kacang peranakan ettawa yang dipelihara pada kandang model panggung sebesar 100\%. Hasil ini hampir sama dengan hasil penelitian yang dilaporkan oleh Donald (2003) yang menyimpulkan bahwa prevalensi $H$. contortus kambing dan domba di Ethiopia sebesar 98,8\%. Namun hasil penelitian ini lebih tinggi dibandingkan dengan hasil penelitian yang dilaporkan oleh Mukti et al. (2014) prevalensi cacing nematoda saluran pencernaan pada kambing PE adalah sebesar 51,9\%, dan 51,4\% 
pada kambing di RPH Banda Aceh (Hanafiah et al., 2002). Sementara Nugroho (2013) mengemukakan bahwa prevalensi cacing nematoda saluran pencernaan pada kambing yang dipelihara pada model kandang panggung tanpa sekat $66,21 \%$ dan dengan sekat 58,26\%.

Tabel 1. Distribusi infestasi cacing saluran pencernaan pada kambing Kacang Peranakan Ettawa (KPE) berdasarkan tingkat umur yang dipelihara di kandang model panggung.

\begin{tabular}{lccc}
\hline $\begin{array}{c}\text { Umur } \\
\text { kambing } \\
\text { KPE }\end{array}$ & $\begin{array}{c}\text { Total } \\
\text { jumlah } \\
\text { sampel }\end{array}$ & $\begin{array}{c}\text { Jumlah } \\
\text { sampel } \\
\text { terinfestasi }\end{array}$ & $\begin{array}{c}\text { Persentase } \\
\text { infestasi } \\
(\%)\end{array}$ \\
\hline $\begin{array}{l}1-4 \\
\text { bulan }\end{array}$ & 8 & 8 & 100 \\
$5-14$ & 5 & 5 & 100 \\
bulan & 9 & 9 & 100 \\
$\begin{array}{l}15-24 \\
\text { bulan } \\
>25\end{array}$ & 10 & 10 & 100 \\
bulan & T2 & $\mathbf{3 2}$ & $\mathbf{1 0 0}$ \\
\hline Total & $\mathbf{3 2}$ & &
\end{tabular}

Jenis parasit cacing yang ditemukan pada ternak kambing berdasarkan hasil pemeriksaan laboratorium antara lain: Strongyle sp, Strongyloides sp. Haemonchus spp., Bunostomum spp., Trichostrongilus spp. dan Cooperia sp. Hal ini sesuai dengan temuan lain tentang prevalensi parasit gastrointestinal pada sapi, kambing dan domba juga ditemukan di Kenya (Pfukenyi et al., 2007). Sementara nematoda saluran pencernaan yang ditemukan pada ternak kambing di Indonesia adalah Haemonchus contortus, Trichostrongylus spp., dan Oesophagostomum columbianum (Adiwinata dan Sukarsih, 1992).

Berdasarkan pemeriksaan laboratorium dari 32 ekor kambing ini, semua sampel teridentifikasi mengalami infestasi secara campuran oleh beberapa jenis cacing. Pada beberapa penelitian juga melaporkan bahwa prevalensi terjadinya infestasi campuran oleh beberapa jenis cacing cukup tinggi dapat mencapai 90\% (Dessalegn, 1999). Tingginya tingkat infestasi campuran ini dapat terjadi diduga karena kurang efisiennya metode kontrol kesehatan pada ternak yang diterapkan. Peternak jarang mengambil tindakan-tindakan khusus seperti memisahkan hewan sakit dari kelompoknya, memberikan vitamin, memberikan pengobatan sesuai dengan gejala yang terlihat malah justru ternak yang sakit dibiarkan tetap bergabung dengan kelompoknya.
Tingkat kejadian infestasi cacing saluran pencernaan antar kelompok umur kambing tidak berbeda satu sama lain, semua kelompok umur terinfestasi oleh cacing saluran pencernaan. Tingginya tingkat kejadian infestasi cacing saluran pencernaan pada kambing kacang peranakan ettawa walaupun ternak sudah dikandangkan pada kandang panggung bersekat, disebabkan karena manajemen pemeliharaan yang diterapkan masih semi intensif. Ternak akan dikeluarkan dari kandang dan diumbar di pekarangan pada pukul 10.00 WIT sampai dengan pukul 15.00 WIT setelah itu ternak kembali dikandangkan. Tingginya kejadian infestasi oleh cacing nematoda diduga kuat terjadi terutama pada saat makan rumput di padang umbaran/gembalaan yang sudah tercemar oleh larva infektif cacing. Selain itu pakan hijauan yang berupa rumput tetap diberikan saat ternak berada di kandang, sehingga hal inilah yang memunculkan dugaan bahwa ternak kambing tersebut dapat terinfestasi oleh cacing yang memiliki siklus hidup secara langsung seperti cacing nematoda.

Tolistiawaty et al. (2016) mengemukakan bahwa cara pemeliharaan hewan ternak sangat berpengaruh terhadap kejadian infeksi parasit. Jika peternak menggunakan sistem semi intensif dengan membiarkan ternak mencari makan sendiri (sistem gembala) atau sama sekali tidak dikandangkan (sistem tradisional) maka peluang besar terinfeksi cacing sangat besar. Pada hewan ternak yang dipelihara secara intensif (sistem kandang), resiko infeksi dapat dikurangi karena pakan ternak diberikan di dalam kandang.

Kambing kacang peranakan ettawa yang terinfestasi oleh cacing saluran pencernaan dan didominasi oleh jenis strongyle diduga berkaitan dengan pola pemeliharaan yang menggunakan kandang model panggung sehingga menjauhkan ternak dari kontak dengan telur infektif yang keluar bersama feses. Larva cacing ini secara teoritis dapat menginfeksi ternak di kandang atau bahkan auto-infeksi karena telur cacingnya sudah berisi larva dan cepat sekali menetasnya. Namun sumber penularan diperkirakan berasal dari pakan rumput yang diambilkan dari tegalan atau kebun. Rumput tersebut telah terinfestasi oleh larva infektif yang cenderung tergeletak di tanah atau bagian bawah rumput yang lembab. Hal ini didukung oleh penelitian yang dilakukan oleh Nugroho (2013) bahwa perbedaan model kandang bukan merupakan faktor utama penyebab terjadinya infeksi 
nematoda usus pada kambing. Peternak memberikan pakan hijauan pada ternak kambing setiap pagi berupa rumput gajah segar tanpa proses pelayuan. Hijauan segar yang diberikan inilah yang menjadi salah satu faktor penyebab tingginya infestasi cacing saluran pencernaan pada ternak kambing akibat pencemaran larva pada hijauan.

Faktor lain yang mempengaruhi penyebaran cacing nematoda adalah sanitasi dan kebersihan kandang. Kotoran yang dibiarkan menumpuk di dalam kandang akan mengundang lalat dan juga memungkinkan larva nematoda berkembang di dalamnya. Apabila kulit ternak bersentuhan dengan kotoran tersebut, maka beberapa larva cacing dapat masuk ke dalam tubuh ternak. Menurut Subekti et al. (2002) dalam Sugiarti (2006), larva Bunostomum dan Strongyloides memiliki kemampuan untuk menembus kulit inang.

Ternak muda lebih peka terhadap infeksi nematoda dibandingkan dengan yang ternak dewasa (Wakelin, 1984), maka respon kekebalan pada kelompok anak terhadap keterbatasan "feed intake" ini akan lebih serius dibandingkan dengan ternak dewasa. Daerah di Indonesia pada umumnya daya tampung padang gembalaan dan kualitas rumputnya tidak jelas, demikian juga jumlah waktu yang dihabiskan oleh ternak untuk merumput juga berbeda. Hal ini akan memperburuk status kesehatan ternak yang terinfestasi oleh cacing. Tingkat kematian yang disebabkan oleh infestasi cacing gastrointestinal ini terjadi pada anak kambing berjumlah lima ekor dalam waktu satu bulan. Dengan adanya infeksi oleh cacing saluran pencernaan maka akan terjadi gangguan-gangguan yang berupa rendahnya tingkat pertumbuhan dan bertambahnya tingkat kematian

(Beriajaya dan Stevenson, 1986).

Kerugian karena infestasi cacing menurut Direktorat Jenderal Peternakan (2010) mencapai 4 milyar rupiah per tahun dan merupakan penyakit yang dapat mempengaruhi produktivitas, kekurusan, penurunan daya produksi bahkan pada infeksi berat dapat menyebabkan gangguan pencernaan hingga terhambatnya pertumbuhan hewan itu sendiri. Efek lain yang ditimbulkan yakni penurunan berat badan akibat diare dan efek pada hospesnya.

\section{SIMPULAN}

Kejadian infestasi cacing saluran pencernaan pada kambing kacang peranakan ettawa yang dipelihara secara semi intensif sebesar $100 \%$. Jenis cacing saluran pencernaan yang menginfeksi kambing kacang peranakan ettawa adalah Strongyle sp, Strongyloides sp, Haemonchus spp, Bunostomum spp, Trichostrongilus spp, dan Cooperia spp.

\section{DAFTAR PUSTAKA}

Adiwinata, G., dan Sukarsih. 1992. Gambaran Darah Domba yang Terinfeksi Cacing Nematoda Saluran Pencernaan Secara Alami di Kabupaten Bogor. Penyakit Hewan. 24(43): 13-16.

Animut, G., A.I. Goetsch, G.E. Aiken, R. Puchala, G. Detweiler, C.R. Krehbiel, R.C. Merkel, T. Sahlu, and L.J. Dawsin. 2005. Grazing behavior and energy expenditure by sheep and goats cograzing grass forb pastures at three stocking rates. Small Rumin Res. 59: 191201.

Ayaz, M.M., M.A. Raza, S. Murtaza and S. Akhtar. 2013. Epidemiological survey of helminths of goats in southern Punjab, Pakistan. Trop. Biomed. 30: 62-70.

Beriajaya and P. Stevenson. 1986. Reduced Productivity on Small Ruminants in Indonesia as a Result of Gastrointestinal Nematode Infections. Proc. 5th Int.Conf.Lvstk.Dis.Trop. 28-30.

Dessalegn, L., 1999. The Epidemiology of Strongyle infections in small ruminants under warm tropical climate. J. Vet. Res., 71(3): 219-226. Proceedings of the $13^{\text {th }}$ Annual Conference of Ethiopian Veterinary Association. Addis Ababa, Ethiopia.

Ditjennak, 2014. Statistik Peternakan 2014. Direktorat Jenderal Peternakan. Departemen Pertanian. Jakarta.

Direktorat Jendral Peternakan. 2010. Epidemiologi Kejadian Penyakit Nematodiasisdi Indonesia. Departemen Pertanian. Jakarta.

Donald, A.K. 2003. Epidemiology and Seasonal Dynamics of Gastrointestinal Helminthoses of Small Ruminant in Easthern and Southern Semi Aridzones of Ethiopia. $\quad \underline{\text { http://wwwl.vetmed.fu }}$ berlin.de/ip-4donald.html

Garedaghi, Y., A.P. Rezaii-Saber, A. Naghizadeh and M. Nazeri. 2011. Survey on prevalence of sheep and goats lungworms in Tabriz abattoir, Iran. $A d v$. Environ. Bio. 5: 773-775.

Hanafiah, M., Winaruddin, dan Rusli. 2002. Studi infeksi nematoda gastrointestinal pada kambing dan domba di rumah 
potong hewan Banda Aceh. J. Sain Vet. 20 (1):14-18

Hassan, M.M., M.A. Hoque, S.K.M.A. Islam, S.A. Khan, K. Roy and Q. Banu. 2011. A prevalence of parasites in Black Bengal goats in Chittagong, Bangladesh. Int. J. Livestock Prod. 2: 40-44.

Kanyari, P., W. Kagira, and R. Mhoma. 2009. Prevalence and intensity of endoparasites in small ruminants kept by farmers in Kisumu Municipality, Kenya. Livestock Res. Rural Develop. 21: 12-15.

Levine, D. 1990. Edisi Indonesia: Parasitologi Veteriner. Gadjah Mada University Press. Yogyakarta. Original Edition: Textbook of Veterinary Parasitology.

Mukti, T., I.B.M. Oka, dan I.M. Dwinata. 2014. Prevalensi Cacing Nematoda Saluran Pencernaan pada Kambiing Peranakan Ettawa di Kecamatan Siliragung, Kabupaten Banyuwangi, Jawa Timur. Indonesia Medicus Veteriner. 5(4): 330-336.

Mulatu, M., T. Fentahun and B. Bogale. 2012. Gastrointestinal Helminthes Parasites in Sheep: Prevalence and Associated Risk Factors, in and Around Gondar Town, Northwest Ethiopia. Advan. Biol. Res. 6 (5): 191-195.

Nugroho, R.Z. 2013. Jenis dan Prevalensi Nematoda Usus Pada Kambing Yang Dipelihara Dengan Model Kandang Yang Berbeda di Kecamatan Sumbang Kabupaten Banyumas. Tesis. Fakultas Biologi. Universitas Jenderal Soedirman.

Pamungkas, F.A., A. Batubara, M. Doloksaribu, and E. Sihite. 2009. Potensi Beberapa Plasma Nutfah Kambing Lokal Indonesia. Juknis (ID). Pusat Penelitian dan Pengembangan Peternakan, Badan Penelitian dan Pengembangan Pertanian, Departemen Pertanian.

Pfukenyi, M.D, S. Mukaratirwa, A.L. Willingham, dan J. Monrad. 2007. Epidemiological studies of parasitic gastrointestinal nematodes, cestodes, and coccidia infections in cattle in the highveld and lowveld communal grazing areas of Zimbabwe. Journal of Veterinary Research. 74: 129-142.

Schoenian, S. 2003. Integrated Parasite Management (IPM) in Small Ruminants. [Internet][diunduh pada 18 Juni 2015] : tersedia pada: http://www. Sheep and goat. com/articles/IPM. html.

Sugiarti, 2006. Identifikasi Nematoda Gastrointestinal pada Banteng (Bos javanicus d' Alton) di Taman Nasional Alas Purwo Kabupaten Banyuwangi Melalui Pemeriksaan Feses. Skripsi. Fakultas Kedokteran Hewan Universitas Airlangga. Surabaya

Suhardono, Beriajaya, dan D. Yulistiani. 2001. Gastro-intestinal infection in sheep reared extensively in high populated stock area in the province of West Java. Prosiding Inovasi Teknologi Pertanian (ID): Badan Penelitian dan Teknologi Pertanian.

Terefe, D., D. Demissie, D. Beyene and S. Haile. 2012. A prevalence study of internal parasites infecting Boer goats at Adami Tulu agricultural research center, Ethiopia. J. Vet. Med. Anim. Health. 4: 12-16.

Thienpont D, F. Rochette, O.F.J. Vanparijs. 1986. Diagnosing Helminthiasis by Coprological Examination. Jansenn Reseach Foundation. Beerse. Belgium.

Thrusfield, M., 2007. Veterinary Epidemiology. Third Edition. Blackwell Publising.

Tolistiawaty I, J. Widjaja, L. T. Lobo, R. Isnawati. 2016. Parasit Gastrointestinal Pada Hewan Ternak di Tempat Pemotongan Hewan Kabupaten Sigi, Sulawesi Tengah. BALABA. Vol. 12 (2). $71-78$.

Wakelin, D. 1984. Immunity to Parasites . How animals Control Parasite Infections. Edward Arnold Ltd . Pp. 98-109. (12) : 357-362.

Zeryehun, T. 2012. Helminthosis of sheep and goats in and around Haramaya, Southeastern Ethiopia. J. Vet. Med. Anim. Health 4: 48-55. 